\title{
THE EFFECT OF INSULIN ON BLOOD LEVELS OF INFUSED PENTOSES IN MAN
}

\author{
By STANTON SEGAL, JAMES B. WYNGAARDEN,1 AND JOSEPH FOLEY \\ (From the National Institute of Arthritis and Metabolic Diseases, National Institutes of Health, \\ Public Health Service, U. S. Department of Health, Education and Welfare, \\ Bethesda, Md.)
}

(Submitted for publication December 17, 1956; accepted June 6, 1957)

In 1931 Wierzuchowski (1) showed an influence of insulin on galactose tolerance of dogs. More recently, Levine, Goldstein, Huddlestun, Klein, and Henry $(2,3)$ demonstrated that insulin lowers the blood levels of D-galactose, D-xylose, and L-arabinose but not of D-arabinose or D-mannose, following their infusion into the eviscerated nephrectomized dog. The volume of distribution of the responsive sugars was increased from 45 to 70 per cent of body weight as a result of insulin administration. It was suggested that the insulin response represented a facilitation of transport of the sugar across the cell membrane into intracellular fluid. In all the responsive sugars the stereochemical structure of carbon atoms 1 to 3 was like that of D-glucose, and these authors suggested that these structural characteristics determined the insulin responsiveness of a sugar.

Confirmatory evidence has appeared that insulin affects transport of D-galactose, D-xylose and L-arabinose across the cell membrane in the rat diaphragm (4-6), eviscerate rat (7), perfused rat heart (8) and intact cat (9). However, slow penetration of a number of sugars into muscle of nephrectomized and eviscerated rats has now also been demonstrated, and this slow penetration is increased by insulin for D-lyxose, D-ribose, D-mannose, D-fructose and D-fucose, as well as for D-xylose, D-galactose and L-arabinose $(10,11)$. Although these results indicate that the concept of structural specificity in carbon atoms 1 to 3 for insulin responsiveness has proved to be too limited in scope, the lack of an effect of insulin upon intracellular entry of sorbitol, mannitol and raffinose is strong evidence that the action of insulin is not simply an acceleration of a process of physical diffusion (12).

1 Present address : Department of Medicine, Duke University School of Medicine, Durham, N. C.
No reports have been noted demonstrating an effect of insulin on a sugar other than glucose in man. This paper reports studies on the effect of insulin on blood levels of infused pentoses in man. Pentoses were selected because their responses to insulin in animals have been well described, they are readily available, and following intravenous infusion they disappear from blood relatively slowly. This latter property permitted an evaluation of the effect of insulin upon blood levels and disappear-
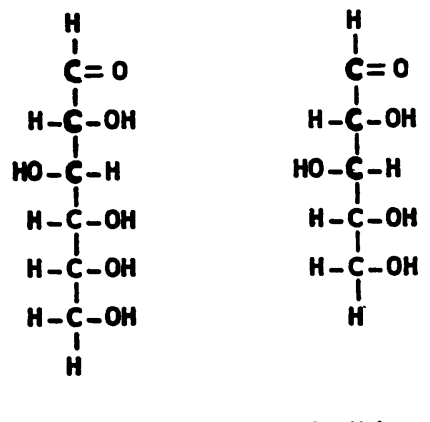<smiles>O=CC(O)C(O)C(O)CO</smiles>

D-Glucese

$$
\text { D-Xylose }
$$

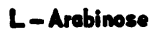<smiles>O=CC(O)C(O)C(O)C(O)CO</smiles>

D-Arebinose
D-Lyxose

Fig. 1. The Stereochemical Configuration of the Pentoses Used in the Present Study

The carbons in bold type indicate those atoms whose configuration is similar to that of glucose in the first three atoms. 
ance rates, an appraisal which could not be made with galactose (13) or fructose (14), which disappear from blood even more rapidly than does glucose (15). In the present studies, we have investigated the influence of insulin upon the rate of pentose disappearance from blood, and upon the urinary excretion of pentose.

The stereochemical configuration of the sugars used in the present experiment is shown in Figure 1. Although these sugars exist in solution in a more complex pyranose ring structure, the simplified formulas shown here demonstrate certain differences in structure. D-xylose and L-arabinose have structures exactly like glucose in the first three carbon atoms. D-arabinose differs in spatial projection of hydrogen and hydroxl groups on carbons 2 and 3, and D-lyxose on carbon 2 alone. $\mathrm{D}$-lyxose is the pentose whose structure in carbon atoms 1 to 4 resembles that of the hexose D-mannose. Because of the unusual kinetics of disappearance of D-ribose from blood, the effects of insulin on D-ribose blood levels will be reported in a subsequent communication.

\section{METHODS}

Eleven studies were performed on five normal males and one female ranging in age from 18 to 28 . All were maintained on a $250-\mathrm{Gm}$. carbohydrate diet and were fasted overnight prior to any study. An indwelling plastic catheter was placed in an antecubital vein, and control blood specimens taken. A three-way stopcock was then attached and kept open with a very slow infusion of saline. Ten- or $20-\mathrm{Gm}$. quantities of pentose, as a 10 per cent solution, were then infused into a vein of the opposite arm. A blood sample was drawn from the indwelling catheter at the end of the infusion and a period of 25 to 30 minutes was then permitted to elapse in order to insure adequate mixing of the sugars in body fluids. At the end of this period blood samples were drawn at 5- or 10-minute intervals for 25 to 30 minutes. At this time ( 50 to 60 minutes after the end of the pentose infusion), when enough blood values had been obtained to establish a curve of the falling blood levels, 0.1 unit of regular insulin was injected intravenously per $\mathrm{Kg}$. of body weight. Blood specimens were drawn at 5- to 15-minute intervals for another 90 to 110 minutes. In some experiments intravenous glucose (10 per cent solution) was given after insulin injection. In three of the studies sugars were infused at a constant rate after administration of a priming dose and the effect of insulin on the constant pentose level obtained was evaluated.

Urine was collected at various intervals over a 24-hour period.

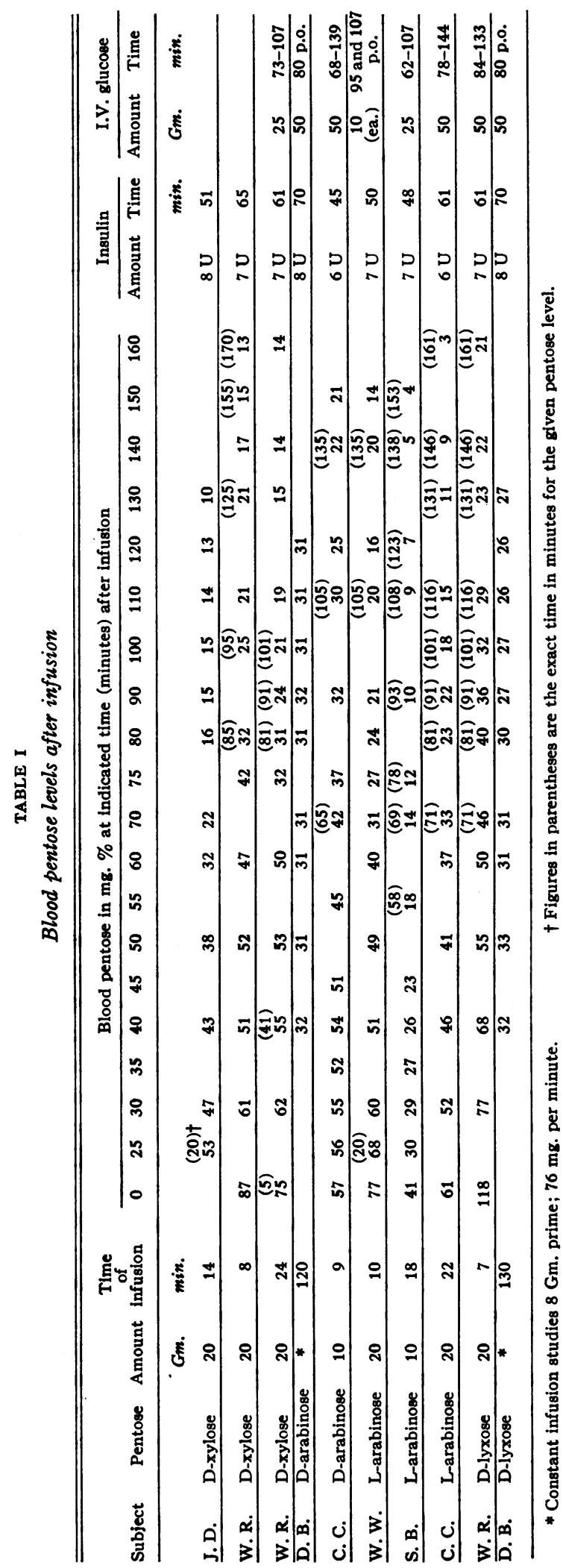


All of the pentoses initially employed were obtained from Dr. Hewitt G. Fletcher, Jr., of the Section on Carbohydrates, Laboratory of Chemistry of this Institute, and recrystallized before use. All had specific optical rotations corresponding with those of the pure sugars reported in the literature (16). Subsequently, D-xylose and
L-arabinose were obtained from Pfanstiehl Laboratories, Incorporated, Waukegan, Illinois. The sugars were prepared for intravenous use by autoclaving as 10 per cent solutions, and were found sterile and pyrogen-free prior to use.

Blood glucose and pentose levels were determined by

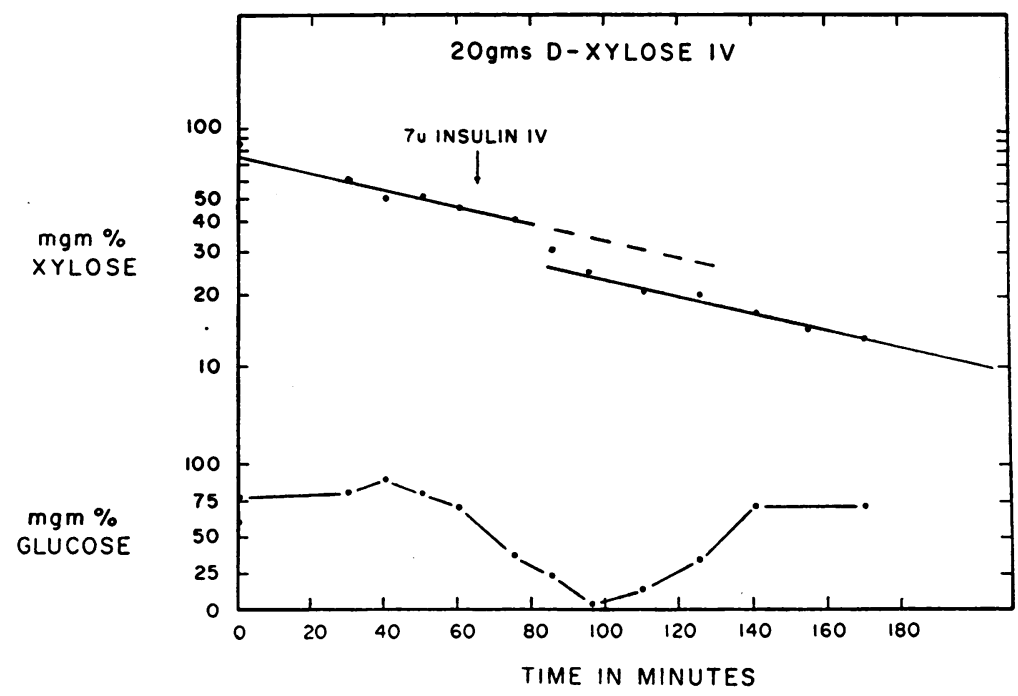

Fig. 2. The Effect of Insulin Administration on Blood Levels of D-Xylose (Subject W. R.)

Blood xylose levels are plotted hemilogarithmically versus time. Blood glucose values are plotted on normal ordinates.

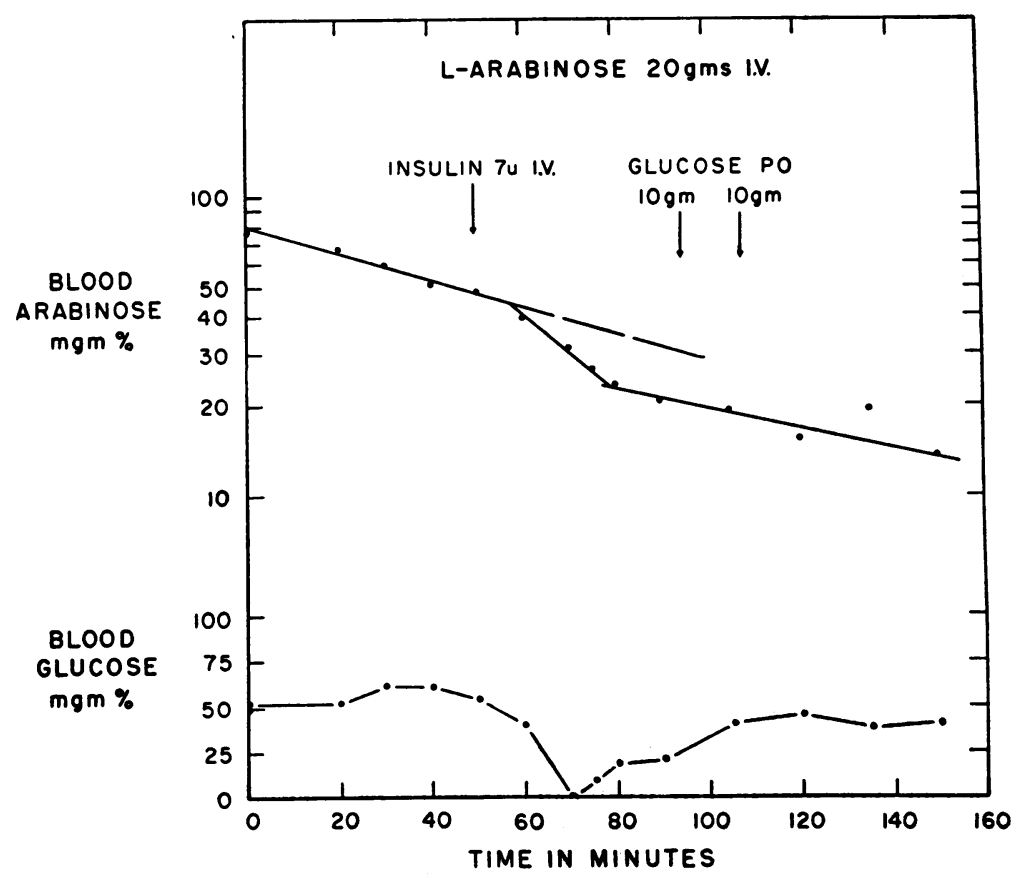

Fig. 3. The Effect of Insulin on the Blood Levels of L-Arabinose (SubJECT W. W.) 


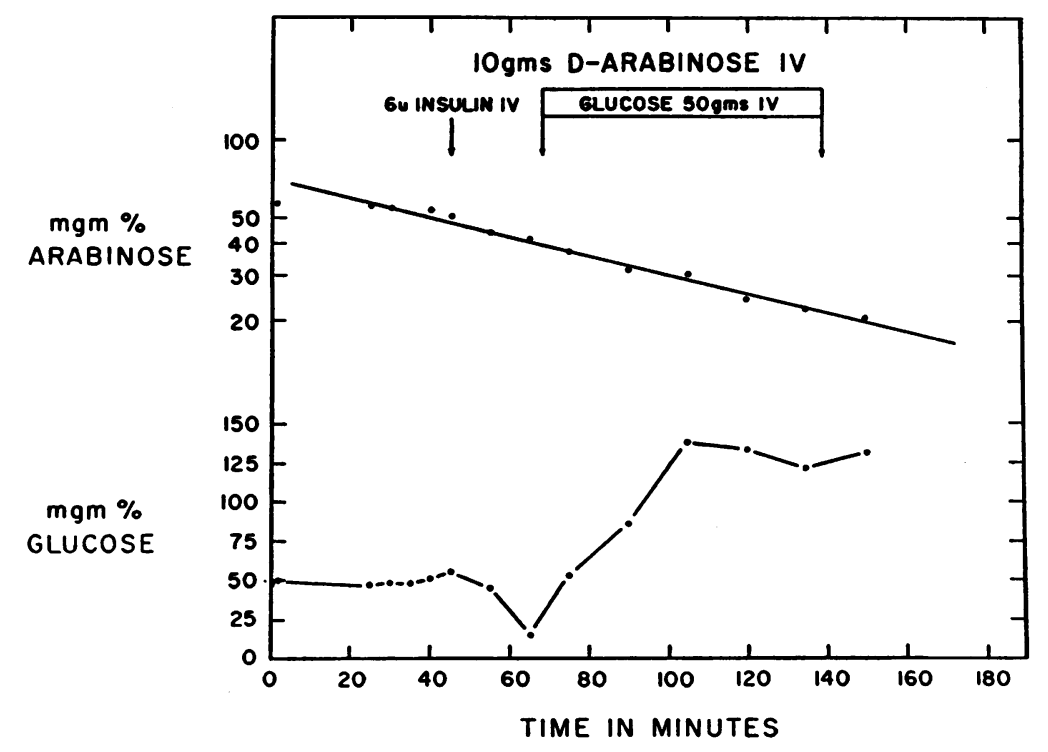

Fig. 4. The Lack of Response of the Blood Levels of D-Arabinose to INJECTEd INSULIN (SubjeCt C. C.)

Glucose was administered to alleviate hypoglycemia.

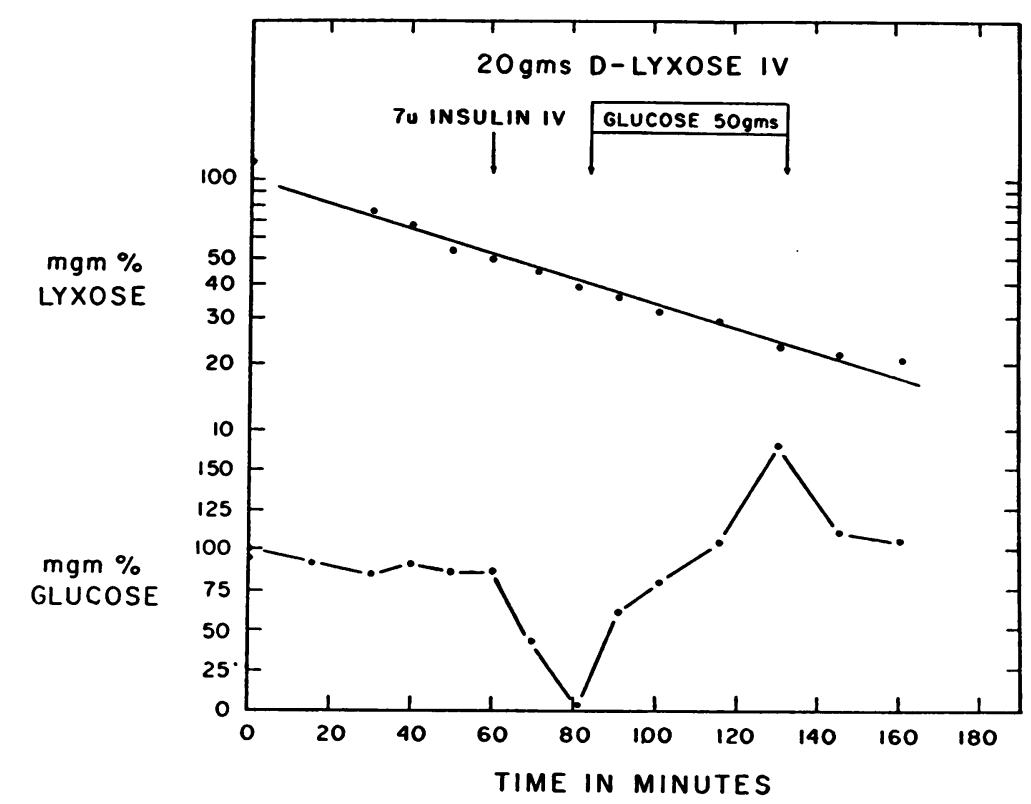

Fig. 5. The Lack of Response of Blood Levels of D-Lyxose to Intravenous INSULIN (SUBJECT W. R.)

methods devised in this laboratory (17). The pentose values were determined by the orcinol method using blood filtrates in which glucose had been destroyed by treatment with the enzyme glucose oxidase. Glucose values were determined by a copper reduction method using the difference between values obtained before and after incubation with the enzyme.

\section{RESULTS}

Effect of insulin upon rates of disappearance of pentose from blood

The results in ten single injection and constant infusion experiments performed are tabulated in 
TABLE II

Biologic half-time and rates of disappearance of infused pentoses

\begin{tabular}{|c|c|c|c|c|c|c|c|c|}
\hline \multirow[b]{2}{*}{ Subject } & \multirow[b]{2}{*}{ Sugar } & \multicolumn{3}{|c|}{$\begin{array}{c}\text { Biologic half-time (T 1/2) } \\
\text { in minutes }\end{array}$} & \multicolumn{3}{|c|}{$\begin{array}{l}\text { Per cent disappearance/min. } \\
(\mathrm{K}) \times 100\end{array}$} & \multirow[b]{2}{*}{$\begin{array}{c}\text { \% Fall in } \\
\text { pentose } \\
\text { level }\end{array}$} \\
\hline & & Initial & $\begin{array}{c}30 \mathrm{~min} . \\
\text { post } \\
\text { insulin }\end{array}$ & Final & Initial & $\begin{array}{c}30 \text { min. } \\
\text { post } \\
\text { insulin }\end{array}$ & Final & \\
\hline $\begin{array}{l}\text { J. D. } \\
\text { W. R. } \\
\text { W. R. } \\
\text { C. C. } \\
\text { W. W. } \\
\text { S. B. } \\
\text { C. C. } \\
\text { W. R. }\end{array}$ & $\begin{array}{l}\text { D-xylose } \\
\text { D-xylose (Fig. 2) } \\
\text { D-xylose (Fig. 8) } \\
\text { D-arabinose (Fig. 4) } \\
\text { L-arabinose (Fig. 3) } \\
\text { L-arabinose (Fig. 9) } \\
\text { L-arabinose } \\
\text { D-lyxose (Fig. 5) }\end{array}$ & $\begin{array}{l}64 \\
86 \\
85 \\
82 \\
68 \\
58 \\
74 \\
63\end{array}$ & $\begin{array}{l}24 \\
27 \dagger \\
29 \\
82 \\
25 \\
28 \\
19 \\
63\end{array}$ & $\begin{array}{r}122 \\
87 \\
80 \\
82 \\
91 \\
47 \\
48 \\
63\end{array}$ & $\begin{array}{l}1.08 \\
0.81 \\
0.82 \\
0.85 \\
1.03 \\
1.19 \\
0.94 \\
1.10\end{array}$ & $\begin{array}{l}2.89 \\
2.57 \\
2.39 \\
0.85 \\
2.77 \\
2.47 \\
3.64 \\
1.10\end{array}$ & $\begin{array}{l}0.57 \\
0.80 \\
0.87 \\
0.85 \\
0.76 \\
1.47 \\
1.447 \\
1.10\end{array}$ & $\begin{array}{r}40 \\
31 \\
38 \\
0 \\
34 \\
26 \\
20 \\
0\end{array}$ \\
\hline
\end{tabular}

* Percentage by which level observed 30 minutes after administration of insulin differs from that calculated at this time by extrapolation of initial curve.

† Figures in italics are estimated.

‡ During this phase a hyperglycemia of $235 \mathrm{mg}$. per cent was induced.

Table I. Graphs of experiments following infusion of $20 \mathrm{Gm}$. of D-xylose (W. R.), and L- and D-arabinose (W. W., and C. C., respectively), and D-lyxose (W. R.) are shown in Figures 2, 3, 4, 5. In these figures the logarithm of the pentose concentration in blood has been plotted against time. In Figure 2 the portion of the curve of D-xylose concentrations obtained from 0 to 75 minutes after infusion demonstrates the hemilogarithmic linear disappearance curve of this pentose from blood. After insulin injection at 65 minutes a latent period of 10 minutes passed before any effect was noted in the xylose level. A marked acceleration in the rate of disappearance of xylose from blood then occurred, lasting about 20 minutes, after which a new disappearance curve of xylose was established. Comparison of the blood xylose level found 30 minutes after insulin administration with that obtained by extrapolation of the initial curve reveals a difference of 30 per cent. Similar results were obtained with L-arabinose as shown by Figure 3. Here, also, a sharp break in the initial disappearance rate occurs shortly after the administration of insulin, and after a 30-minute period of rapid decline in blood pentose level, a new disappearance curve is established. The blood arabinose level measured 30 minutes after insulin administration differs from that obtained by extrapolation of the initial curve by 34 per cent. These experiments are typical of those performed with $\mathrm{D}$-xylose and L-arabinose, and demonstrate a positive response of these sugars to injected insulin (Table II).
In Figures 4 and 5 are shown the responses obtained with $\mathrm{D}$-arabinose and $\mathrm{D}$-lyxose, respectively. It appears that $\mathrm{D}$-arabinose and $\mathrm{D}$-lyxose are unresponsive to insulin. However, the possibility existed that small changes in rate of disappearance and blood level could occur in the 30-minute post insulin period without being detected in this type of experiment. Therefore, two experiments were

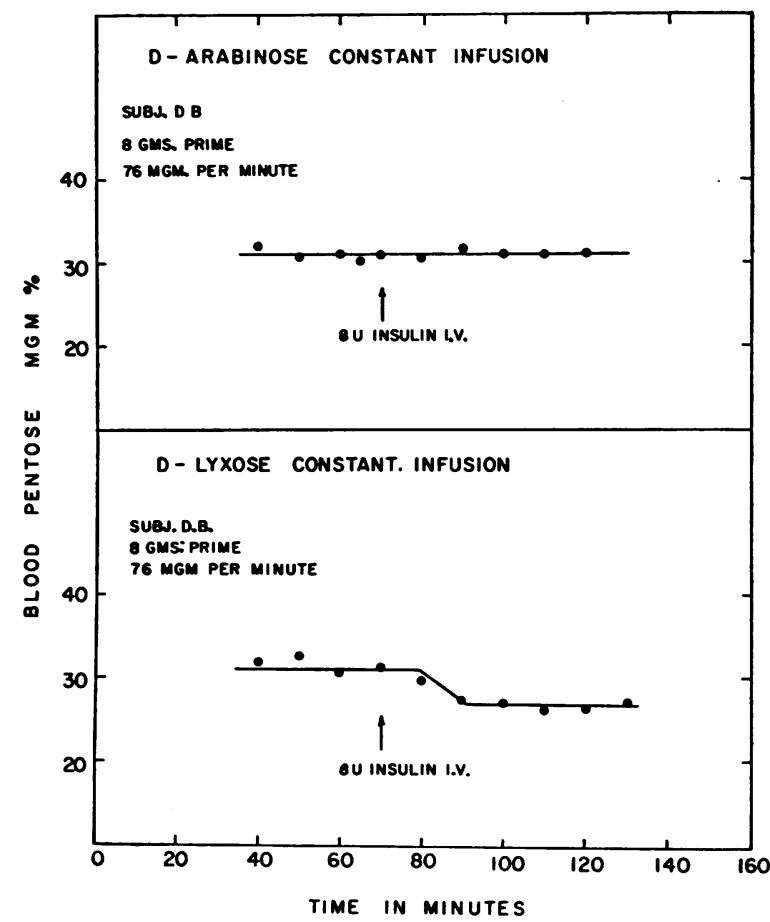

Fig. 6. The Effect of Insulin on Constant Blood LeVels OF D-ARABINose AND D-LyXose 


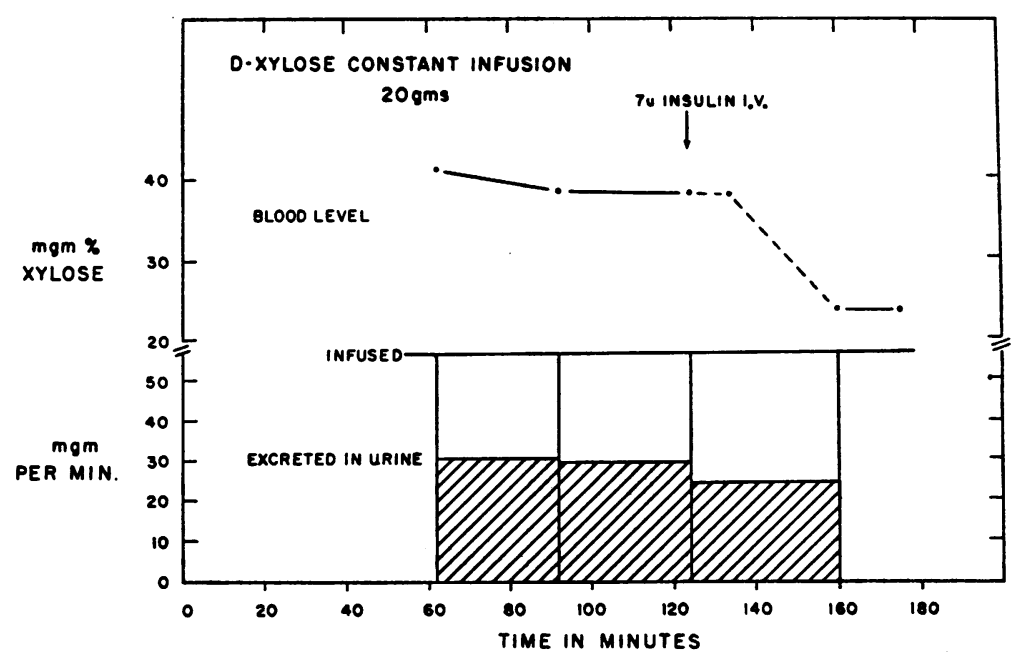

Fig. 7. The Effect of Insulin on Blood Levels and Urinary Excretion of D-XYLose (Subject W. R.)

The fall in blood levels of $\mathrm{D}$-xylose resulting from insulin administration cannot be attributed to an increase in urinary excretion.

carried out employing a constant infusion technique. After a priming dose the pentose was infused at a slow constant rate by means of a Bowman pump. When a constant blood level had been established insulin was injected intravenously and the effect on the constant pentose level observed. The results of this type of experiment in Subject $D$. B. with D-arabinose and D-lyxose are shown in Figure 6. It is apparent that no detectable change occurred in the constant level of D-arabinose. However, within a 10-minute interval insulin caused a decrease of 13 per cent in the constant D-lyxose level. Maintenance of the lowered lyxose level without altering the infusion rate suggests that after the insulin effect there was a resumption of the pre-insulin disappearance rate. These results indicate that $\mathrm{D}$-arabinose is unresponsive but that $\mathrm{D}$-lyxose is responsive to insulin. The magnitude of the response of D-lyxose, however, is small and could be undiscernable by the single injection technique. These results with $D$-arabinose and D-lyxose shown in Figure 6 are in marked contrast to the 38 per cent response of $D$-xylose which was studied by the same technique (Figure 7).

The values for biological half-times $\left(\mathrm{T}^{1} / 2\right)$, per cent disappearance per minute $(K)$ and insulin response of the various pentoses are shown in Table II. In the D-xylose experiments in W. R. (Figures 2 and 8 ) the initial and final xylose dis- appearance rates are almost identical despite the interposition of a half-hour period of rapid disappearance. The D-xylose study in J. D. reveals a final disappearance rate which is much slower than the initial. Some variability of initial and final rates is seen in the L-arabinose studies. W. W. (Figure 3) demonstrates a slower final rate, whereas S. B. (Figure 9) and C. C. (Figure 4) show slightly faster rates.

In the L-arabinose study of W. W. (Figure 3) enough points were obtained in the half-hour after insulin to permit a calculation of values for the rapid disappearance phase. The $\mathrm{T} 1 / 2$ is 25 minutes for this curve, indicating an almost three-fold increase in disappearance rate in the short period following insulin administration. The same calculation can be made for D-xylose from the data on $J$. D. and again the rate increase is nearly threefold. Not enough points were obtained in the 30-minute period post insulin in the other studies with D-xylose and L-arabinose to yield an accurate curve. However, if one estimates the minimal rate of disappearance in this period from a theoretical line connecting the last value of the initial curve with the first value of the final curve, one finds rates very similar to those actually determined in other studies.

Table II also indicates the degrees of response of the pentoses to insulin as measured by the single 


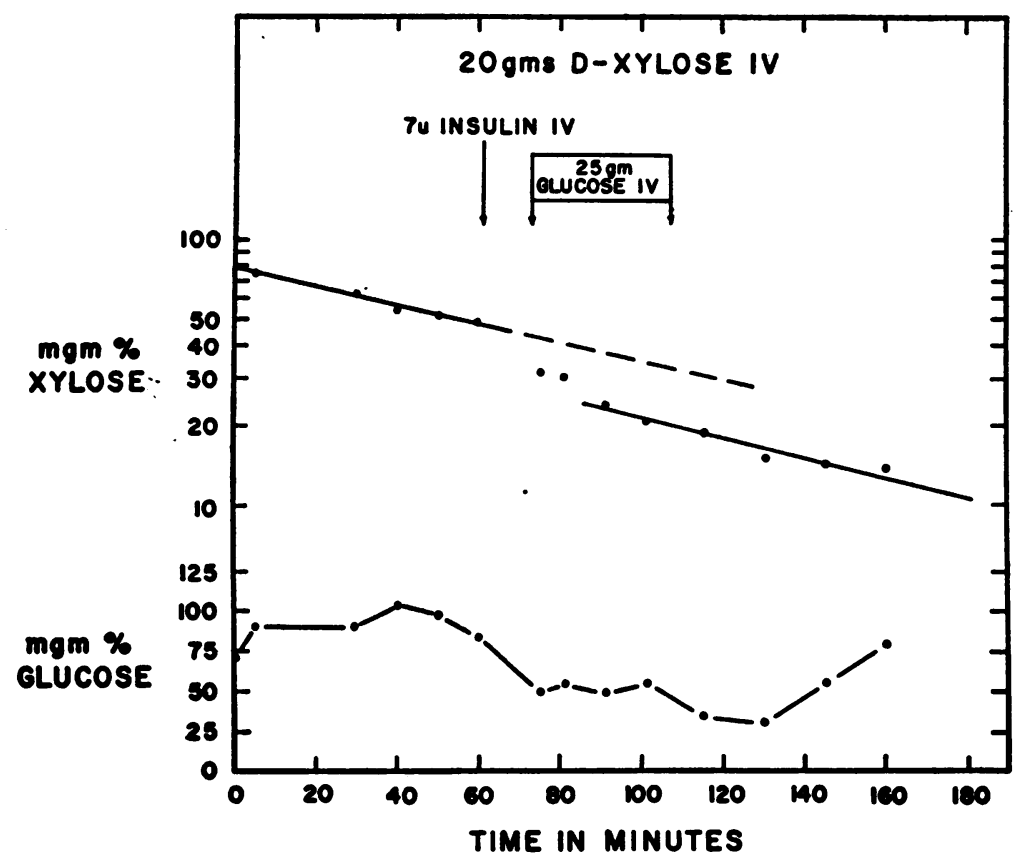

Fig. 8. The Failure of Intravenous Glucose Administration to Abolish the Effect of Insulin on Disappearance of D-Xylose From BLOOD (SUBJECT W. R.)

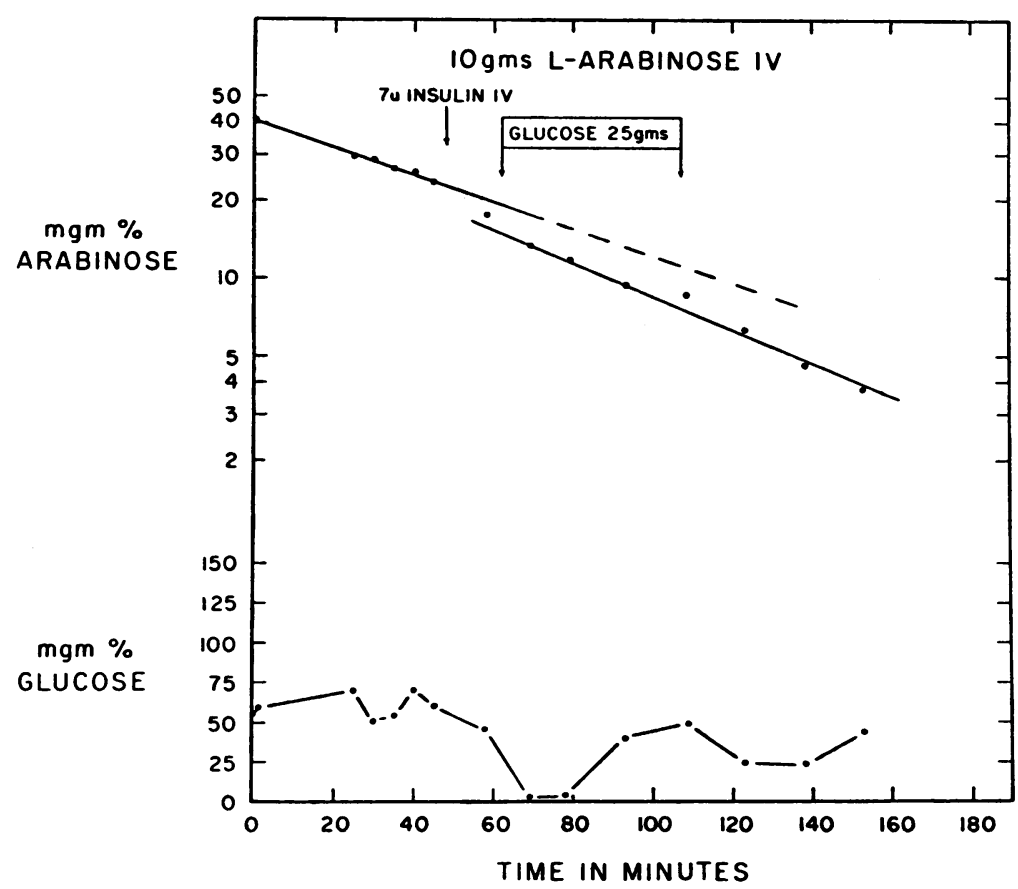

Fig. 9. The Dissociation of the Insulin Effect from Hypoglycemia Per Se (Subject S. B.)

The insulin response of the pentose has terminated though blood glucose values remain at low levels. 
injection technique. D-xylose showed a 31 to 40 per cent fall, and results were quite reproducible in two studies in W. R. L-arabinose responses were very similar to those of xylose. D-arabinose and D-lyxose have a zero response, although D-lyxose by the constant infusion technique showed a 13 per cent response.

The data presented indicate that with the responsive pentoses the insulin action is limited to a half-hour period after injection, during which time the disappearance of pentose is enhanced up to three-fold. After this period there is a return to rates of disappearance approximating those initially observed without insulin. This final disappearance rate is established at blood levels from 13 to 40 per cent lower than would be expected had no insulin been given.

\section{Relationship of pentose response to insulin to the blood glucose level}

The response of $\mathrm{D}$-xylose and L-arabinose as shown in Figure 2 and Figure 3 was observed in the presence of very low blood glucose values. In order to dissociate the pentose response to insulin from hypoglycemia per se, several studies were performed in which $\mathrm{D}$-glucose was infused shortly after the injections of insulin. Figure 8 shows a second study with D-xylose performed in the same individual (W. R.) whose earlier study is shown in Figure 2. Here an infusion of $25 \mathrm{Gm}$. of glucose maintained the blood glucose level at $50 \mathrm{mg}$. per cent over the period when a decrease in blood xylose levels was anticipated. The response of xylose to insulin occurred as before, and almost identical rate constants for the curves were calculated (Table II). A similar study with L-arabinose (C. C., Table I) also demonstrated that maintenance of a normal blood sugar, by glucose infusion, did not prevent the usual response of this pentose to insulin.

Perhaps the best example of dissociation of pentose response and hypoglycemia is shown in Figure 9 (S. B.). In this study the augmentation of L-arabinose disappearance occurred as the blood glucose level fell to $2 \mathrm{mg}$. per cent at 69 minutes. However, despite the continuation of hypoglycemia, the slope of the disappearance curve of $\mathrm{L}$-arabinose returned to a value similar to that prior to insulin administration. This indicates that a low blood glucose level per se is not a factor affecting the increased rate of L-arabinose disappearance.

Hypoglycemia itself does not influence the rate of disappearance of those sugars unresponsive or slightly responsive to insulin. Thus, in Figures 4 and 5 , though the blood glucose is less than $5 \mathrm{mg}$. per cent, the disappearance curves of $\mathrm{D}$-arabinose and D-lyxose continue in a smooth uninterrupted descent. In these two studies hyperglycemia produced by glucose infusion was without effect on the rates of decline of pentose levels.

Though D-xylose and L-arabinose are readily responsive to insulin, our results do not suggest that these sugars stimulate the pancreas to secrete insulin. No fall in blood sugar was observed following infusion. In fact, as previously seen (17), after infusion of these sugars there is a rise in blood glucose, suggesting they may be glucogenic. However, neither these sugars nor D-arabinose or D-lyxose, though present at levels of 30 to $40 \mathrm{mg}$. per cent, were able to prevent the hypoglycemic symptoms experienced by those individuals with low blood glucose levels.

\section{Urinary excretion of pentoses}

Table III presents the total urinary excretion of pentoses in the experiments described, plus several others. The total excretions are in the range reported for normal subjects not receiving insulin $(17,18)$. Two studies are shown in which the excretion of infused sugar was measured in the same individual, both when insulin was given and omitted. In A. R. the excretion of D-xylose was 41 per cent of the administered dose when insulin was given and 44 per cent when it was omitted. In another study in W. W., total L-arabinose excretion was 43 per cent of the dose with insulin and 53 per cent without insulin. These would appear to be insignificant differences, for such variations may occur on repeated studies without insulin in the same individual.

In order to determine whether the increased rate of disappearance of $\mathrm{D}$-xylose from blood in the 30-minute period following insulin administration could be explained by increased urinary excretion during that interval, the experiment shown in Figure 7 was performed. This figure presents data obtained during a constant infusion of 
TABLE III

Urinary excretion of infused pentoses

\begin{tabular}{|c|c|c|c|}
\hline Subject & Sugar infused & Conditions & $\begin{array}{l}\text { \% of dose } \\
\text { excreted }\end{array}$ \\
\hline $\begin{array}{l}\text { W. R. (Fig. 2) } \\
\text { W. R. (Fig. } 8 \text { ) }\end{array}$ & $\begin{array}{l}\text { D-xylose } \\
\text { D-xylose }\end{array}$ & $\begin{array}{l}\text { With insulin } \\
\text { With insulin } \\
\text { and glucose }\end{array}$ & $\begin{array}{l}42 \\
55\end{array}$ \\
\hline $\begin{array}{l}\text { A. R.* } \\
\text { A. R.* } \\
\text { C. C. (Fig. 4) }\end{array}$ & $\begin{array}{l}\text { D-xylose } \\
\text { D-xylose } \\
\text { D-arabinose }\end{array}$ & $\begin{array}{l}\text { With insulin } \\
\text { Without insulin } \\
\text { With insulin } \\
\text { and glucose }\end{array}$ & $\begin{array}{l}41 \\
44 \\
56\end{array}$ \\
\hline $\begin{array}{l}\text { W. W. (Fig. 3) } \\
\text { W. W. }{ }^{*} \\
\text { S. B. (Fig. 9) }\end{array}$ & $\begin{array}{l}\text { L-arabinose } \\
\text { L-arabinose } \\
\text { L-arabinose }\end{array}$ & $\begin{array}{l}\text { Insulin } \\
\text { Without insulin } \\
\text { With insulin } \\
\text { and glucose }\end{array}$ & $\begin{array}{l}43 \\
53 \\
60\end{array}$ \\
\hline W. R. (Fig. 5) & D-lyxose & $\begin{array}{l}\text { With insulin } \\
\text { and glucose }\end{array}$ & 55 \\
\hline
\end{tabular}

* Blood levels not determined in these studies.

D-xylose. After the administration of a priming dose of $10 \mathrm{Gm}$., a constant rate of infusion of 56 mg. per minute was maintained. During this infusion the blood level was essentially constant at $38 \mathrm{mg}$. per cent. Urinary excretion, as shown by crosshatching, occurred at a rate of $30 \mathrm{mg}$. per minute, leaving $26 \mathrm{mg}$. per minute, or 46 per cent of the amount infused unaccounted for. These values obtained at equilibrium compare well with the overall results in this individual, W. R., which show that 42 to 55 per cent of infused D-xylose appeared in urine and with the results of other studies with this sugar [(17) and Table III]. The injection of insulin was followed by a drop of 38 per cent in blood pentose level in 30 minutes. During this time a slight decrease in urinary excretion was noted. Hence, this loss of xylose from blood after insulin injection could not be explained on a renal basis.

\section{DISCUSSION}

Reviews on the mechanism of action of insulin have recently been published by Stadie (19) and by Levine and Goldstein (20), and the subject is further discussed by deDuve (21), Helmreich and Cori (11), and Park and associates (10). Two hypotheses have received recent attention, viz., that insulin accelerates the action of hexokinase and that insulin facilitates the transport of glucose into the cell. This latter hypothesis has recently been modified by Helmreich and Cori (11), yielding in effect a third concept, that insulin affects intracellular metabolism in such a way that in- creased permeability of the cell membrane to sugars is a consequence of this action.

The hypothesis that insulin acts at the level of hexokinase has not been adequately substantiated (19). Similarly, the concept that the insulin response can be explained as an increase in membrane permeability has been criticized, since an increase in physiochemical diffusion should not exclude substances such as sorbitol, mannitol and raffinose (12). The concept that insulin acts to facilitate transport of sugars across the cell membrane to increase intracellular concentration of sugars is consistent with available evidence, except that in the case of glucose, intracellular accumulation cannot be demonstrated under physiological circumstances due to rapid utilization and the inadequacy of methods for measuring minute increments of glucose concentrations. However, under unusual conditions, insulin may also cause free glucose to accumulate intracellularly. Park, Bornstein, and Post (22) demonstrated in the rat diaphragm that when hexokinase was saturated by high glucose levels in the medium, or was inhibited by low temperature, insulin would indeed cause glucose from the medium to accumulate intracellularly.

That insulin causes an increase in free intracellular galactose (7) and L-arabinose (8) content of muscle as well as other sugars (10) has also been demonstrated. This would indicate that metabolism of these sugars in muscle is minimal or does not occur. Park found the latter to be true for L-arabinose (8). The Levine group found also that these sugars were not metabolized by the eviscerated nephrectomized dog, which is essentially a living muscle preparation. The slow entrance of pentose into muscle in the normal rat is measured in hours (11). These findings would suggest that the falling blood levels of these pentoses seen after infusion into intact man are the result primarily of metabolism by the liver and excretion by the kidney. The major roles of liver and kidney are illustrated by the findings of slow disappearance of $\mathrm{D}$-xylose from the blood in cirrhotic subjects (17), and the excretion of about 50 per cent of the infused quantities of pentoses in urine by the subjects of the present study.

In the present study the administration of insulin caused an abrupt increase in the rates of disappearance of D-xylose and L-arabinose and 
D-lyxose from the blood stream, lasting up to 30 minutes, after which time the disappearance rates abruptly decreased and in most studies approximated the initial rates of disappearance as determined before injection of insulin. This response to insulin was not dependent upon development of hypoglycemia, and reached completion despite evidence of continued action of insulin on glucose. From considerations of the dose of insulin injected, of recent evidence of disappearance rates and volumes of distribution of injected insulin (23), and of blood levels of insulin following injections of small amounts (24), it may be estimated that the blood insulin level was three to six times normal at a time when the pentose response was complete. It appears to us unlikely that an increase in rate of pentose metabolism caused by insulin as its primary action would be reflected in the type of response that was observed, namely the abrupt termination of the phase of rapid disappearance of pentose despite the presence of abundant insulin.

Bearn, Billing, and Sherlock (25) have claimed that insulin causes a rapid uptake of glucose by the liver in man. At times other investigators have purported to have shown a direct effect of insulin in vitro upon glucose uptake and glycogen synthesis of rat liver slices (21), but this subject is controversial and other studies suggest that insulin itself has no direct action on carbohydrate metabolism by the liver of the rat (26). However, in view of the findings of Bearn and collaborators, one must consider the possibility that insulin has caused a rapid uptake of D-xylose and L-arabinose by liver in the subjects of this report. There are, however, certain imposing arguments against this interpretation. First, similar responses were demonstrated by Levine and associates $(20,26)$ in dogs from whom livers had been removed. Second, the observations that metabolism of D-xylose is unimpaired in diabetics deprived of insulin (27), and that the rate of disappearance and urinary excretion of infused $\mathrm{D}$-xylose are normal in diabetics off insulin (28), suggest that the hepatic system for handling this pentose is not insulin dependent. Third, Helmreich and Cori (11) have shown in the nephrectomized rat that the insulin effect on pentoses is clearly to increase the amount present in muscle and that the liver being present is not an inter- fering factor in studies of this type. Several studies have clearly shown that uptake of sugars by brain is not influenced by insulin (10). We favor the interpretation that insulin has acted in the present studies to increase the distribution of $\mathrm{D}$-xylose and of L-arabinose and D-lyxose in the intracellular fluids of man primarily in muscle by facilitating their transfer across the cell membrane.

The glucose "space" has been estimated in intact man (29) and in the eviscerated rabbit (30) employing techniques with $\mathrm{C}^{14}$ glucose. Shreeve et al. (29) have found the glucose space to vary only minimally from normal in the human diabetic, and Drury and Wick (30) have shown that insulin does not increase the glucose space in their rabbit preparation. However, one would not necessarily anticipate that insulin would increase the glucose space even though it increased transport of glucose into the cell, for all glucose passing across the cell membrane may normally be rapidly phosphorylated by action of hexokinase. Although the determination of a volume of distribution of metabolized substance involves some error, we have estimated the pentose "space" to be 21 per cent of body weight (17). Assuming this volume, and assuming the changes of 20 to 40 per cent in blood levels of $\mathrm{D}$-xylose and L-arabinose resulting from insulin administration are due to distribution changes, one can calculate the pentose space after a single intravenous injection of 0.1 unit of insulin per kilo of body weight to be about 32 per cent of body weight, or 1.5 times the initial value. This volume of distribution is somewhat lower than that reported by Levine, Goldstein, Huddlestun, and Klein (2) for the dog after insulin administration, but the proportional increase in volume of distribution caused by insulin is the same. The D-lyxose space may be calculated to have increased to only 24 per cent of body weight. The increases in volume of distribution calculated here correspond to those reported by Helmreich and Cori (11) in the nephrectomized rat. These investigators report no significant effect of insulin on $\mathrm{D}$-arabinose volume of distribution. It should be mentioned that since the insulin effect is primarily to increase pentose concentration in muscle (10, 11) calculation of changes in volume of distribution from changes in blood levels will give results less than the average total body water.

A final point requiring comment is the relation- 
ship of insulin responsiveness and structural configuration. That the configuration of carbon atoms 1 to 3 has some significance with respect to insulin responsiveness has been shown only in the eviscerated $\operatorname{dog}(3)$. In the rat $(10,11)$ and rabbit (31) corresponding specificity has not been demonstrated. In man it would appear that although the most responsive sugars, $\mathrm{D}$-xylose and L-arabinose, are related to glucose in carbon atoms 1 to 3 and that $\mathrm{D}$-arabinose, which differs from glucose in carbons 2 and 3 , is unresponsive, D-lyxose differing in carbon 2 alone has a slight degree of responsiveness. Part of this discrepancy may be due to species differences and part may be a matter of rate of pentose transport as determined by the insulin doses given in the various studies. For example, Goldstein, Henry, Huddlestun, and Levine (3) gave a 5-unit insulin prime and a constant infusion of 1 unit per kilo per hour. Helmreich and Cori (11) gave 1 to 2 units per $100 \mathrm{Gm}$. The latter dose on a weight basis is one to two hundred times the dose used in the present study. In man a discernable response of $\mathrm{D}$-xylose to insulin may be seen with as little as 0.05 unit per kilo (32). It would appear that man is more sensitive to insulin than the other animal species tested.

At the present time no general theory of sugar structure explains insulin responsiveness in all species. In the rabbit for example, glucosamine (33) and 2-deoxyglucose (34) both appear to be insulin responsive so that in this species the substituents at carbon 2 are not determining with respect to insulin responsiveness. However, although the membrane transport theory of insulin action cannot be considered proved, we believe this concept to be consistent with the greatest number of experimental observations.

\section{SUMMARY}

The insulin responsiveness of certain pentoses has been investigated in man. Blood levels of $\mathrm{D}$-xylose, L-arabinose and D-lyxose are affected by insulin, whereas those of $\mathrm{D}$-arabinose are not. The observed response consists of an abrupt lowering of the pentose level which appears to be maximal and complete after 30 minutes, at a time when plasma insulin values would be expected to be three to six times the fasting value. The response in man cannot be attributed to increased renal ex- cretion. The results obtained suggest that insulin has affected the volumes of distribution of D-xylose, L-arabinose and D-lyxose in the body fluids of man.

\section{ACKNOWLEDGMENT}

The authors wish to express appreciation to Dr. DeWitt Stetten, Jr. for his helpful interest during the course of this study.

\section{REFERENCES}

1. Wierzuchowski, M., Intravenöse Galaktoseassimilation unter dem Einfluss der Hormone, des Hungers und der Nahrungsfaktoren. Biochem. Ztschr., 1931, 237, 92.

2. Levine, R., Goldstein, M. S., Huddlestun, B., and Klein, S. P., Action of insulin on the 'permeability' of cells to free hexoses as studied by its effect on the distribution of galactose. Am. J. Physiol., 1950, 163, 70.

3. Goldstein, M. S., Henry, W. L., Huddlestun, B., and Levine, R., Action of insulin on transfer of sugars across cell barriers: Common chemical configuration of substances responsive to action of the hormone. Am. J. Physiol., 1953, 173, 207.

4. Haft, D., Mirsky, I. A., and Perisutti, G., Influence of insulin on uptake of monosaccharides by the isolated rat diaphragm. Proc. Soc. Exper. Biol. \& Med., 1953, 82, 60.

5. Kipnis, D. M., and Cori, C. F., Studies of tissue permeability. III. The effect of insulin on pentose uptake by the diaphragm. J. Biol. Chem., 1957, 224, 681.

6. Resnick, O., and Hechter, O., Studies on the permeability of galactose in muscle cells of the isolated rat diaphragm. J. Biol. Chem., 1957, 224, 941.

7. Park, C. R., and Johnson, L. H., Effect of insulin on transport of glucose and galactose into cells of rat muscle and brain. Am. J. Physiol., 1955, 182, 17.

8. Park, C. R., Johnson, L. H., and Wright, John H., Jr., Effect of insulin and alloxan diabetes on glucose transport into cells of perfused rat heart. Federation Proc., 1956, 15, 324.

9. Sacks, J., and Bakshy, S., Effect of insulin on tissue distribution of intravenously injected L-arabinose (abstract). Federation Proc., 1956, 15, 159.

10. Park, C. R., Post, R. L., Kalman, C. F., Wright, J. H., Jr., Johnson, L. H., and Morgan, H. E., The transport of glucose and other sugars across cell membranes and the effect of insulin in Ciba Foundation Colloquia on Endocrinology. London, J. \& A. Churchill Ltd., 1956, 9, 240.

11. Helmreich, E., and Cori, C. F., Studies of tissue permeability. II. The distribution of pentoses between plasma and muscle. J. Biol. Chem., 1957, 224, 663 . 
12. Park, C. R., In discussion of Ref. 10. Ciba Foundation Colloquia on Endocrinology. London, J. \& A. Churchill Ltd., 1956, 9, 264.

13. Stenstam, T., Peroral and intravenous galactose tests. Acta med. Scandinav., 1946, Suppl., 177, 115.

14. Smith, L. H., Jr., Ettinger, R. H., and Seligson, D., A comparison of the metabolism of fructose and glucose in hepatic disease and diabetes mellitus. J. Clin. Invest., 1953, 32, 273.

15. Amatuzio, D. S., Stutzman, F. L., Vanderbilt, M. J., and Nesbitt, S., Interpretation of the rapid intravenous glucose tolerance test in normal individuals and in mild diabetes mellitus. J. Clin. Invest., 1953, 32, 428.

16. Pigman, W. W., and Goepp, R. M., Jr., Chemistry of the Carbohydrates. New York, Academic Press Inc., 1948.

17. Wyngaarden, J. B., Segal, S., and Foley, J., Physiological disposition and metabolic fate of infused pentoses in man. J. Clin. Invest., 1957, 36, 1395.

18. McCance, R. A., and Madder, $K$., The comparative rates of absorption of sugars from the human intestine. Biochem. J., 1930, 24, 795.

19. Stadie, W. C., Current concepts of the action of insulin. Physiol. Rev., 1954, 34, 52.

20. Levine, R., and Goldstein, M. S., On the mechanism of action of insulin in Recent Progress in Hormone Research. New York, Academic Press Inc., 1955, 11, 343.

21. deDuve, C., The hepatic action of insulin in Ciba Foundation Colloquia on Endocrinology. London, J. \& A. Churchill Ltd., 1956, 9, 203.

22. Park, C. R., Bornstein, J., and Post, R. L., Effect of insulin on free glucose content of rat diaphragm in vitro. Am. J. Physiol., 1955, 182, 12.

23. Berson, S. A., Yalow, R. S., Bauman, A., Rothschild,
M. A., and Newerly, K., Insulin- $\mathrm{I}^{\mathrm{mn}}$ metabolism in human subjects: Demonstration of insulin binding globulin in the circulation of insulin treated subjects. J. Clin. Invest., 1956, 35, 170.

24. Vallence-Owen, J., Hurlock, B., and Please, N. W., Estimation of plasma insulin. Lancet, 1954, 266, 983.

25. Bearn, A. G., Billing, B. H., and Sherlock, S., Response of the liver to insulin; hepatic vein catheterization studies in man in Ciba Foundation Colloquia on Endocrinology. London, J. \& A. Churchill Ltd., 1953, 6, 250.

26. Levine, R., and Fritz, I. B., The relation of insulin to liver metabolism. Diabetes, 1956, 5, 209.

27. Loos, M., Studies in the utilization of pentoses in diabetes. Acta med. Scandinav., 1954, 148, 425.

28. Segal, S., and Foley, J., Unpublished observations.

29. Shreeve, W. W., Baker, N., Miller, M., Shipley, R. A., Incefy, G. E., and Craig, J. W., $C^{16}$ studies in carbohydrate metabolism. II. The oxidation of glucose in diabetic human subjects. Metabolism, 1956, 5, 22.

30. Drury, D. R., and Wick, A. N., Insulin and the volume of distribution of glucose. Am. J. Physiol., 1951, 166, 159.

31. Drury, D. R., and Wick, A. N., Mechanism of insulin action. Diabetes, 1955, 4, 203.

32. Segal, S., Frawley, T. F., and Foley, J., Comparison of the effects of tolbutamide and insulin on infused pentoses in man, In preparation.

33. Wick, A. N., Drury, D. R., Nakada, H. I., Barnet, H. N., and Morita, T. N., Glucosamine and the action of insulin. J. Biol. Chem., 1955, 213, 907.

34. Wick, A. N., Drury, D. R., and Morita, T. N., 2-deoxyglucose-a metabolic block for glucose. Proc. Soc. Exper. Biol. \& Med., 1955, 89, 579.

\section{SPECIAL NOTICE TO SUBSCRIBERS}

Post Offices will no longer forward the Journal when you move.

Please notify The Journal of Clinical Investigation, Business Office, 333 Cedar Street, New Haven 11, Conn. at once when you have a change of address, and do not omit the zone number if there is one. 